\title{
The Treatment of Borrowed Nouns in Isichazamazwi SesiNdebele and Isichazamazwi SezoMculo
}

Eventhough Ndlovu, Department of African Languages and Literature, University of Zimbabwe, Harare, Zimbabwe (endlovu@arts.uz.ac.zw)

\begin{abstract}
This article focuses on the lemmatisation of vowel-commencing borrowed nouns and the allocation of borrowed nouns to noun class prefixes in Isichazamazwi SesiNdebele, the first monolingual general-purpose Ndebele dictionary, and Isichazamazwi SezoMculo, the first specialised Ndebele dictionary of musical terms. It adopts a comparative approach, also highlighting the controversies surrounding the status of the initial vowel of the prefix or the pre-prefix in Ndebele and other Nguni languages. It further looks at the challenges and limitations of lemmatising the noun using either the initial vowel of the prefix or the initial letter of the noun stem. It is found that there are some inconsistencies in the lemmatisation of vowel-commencing borrowed nouns and the allocation of borrowed nouns to noun class prefixes in the two dictionaries. These inconsistencies impact negatively on the standardisation and treatment of borrowed nouns.
\end{abstract}

Keywords: LEMMATISATION, MICROSTRUCTURE, MACROSTRUCTURE, USER-PREFERENCE, USER-PERSPECTIVE, USER-FRIENDLY, ACCESSIBILITY, REDUNDANCY, NOUN STEM, NOUN CLASS PREFIX, AUGUMENT, PREFIX PROPER, BORROWED NOUN

Opsomming: Die behandeling van leensubstantiewe in Isichazamazwi SesiNdebele en Isichazamazwi SezoMculo. Hierdie artikel fokus op die lemmatisering van leensubstantiewe met aanvangsklinkers en die toewysing van leensubstantiewe aan substantiefklasprefikse in Isichazamazwi SesiNdebele, die eerste eentalige meerdoelige Ndebelewoordeboek, en Isichazamazwi SezoMculo, die eerste gespesialiseerde Ndebelewoordeboek van musiekterme. Dit gebruik 'n vergelykende benadering sodat ook aandag gegee word aan die strydpunte rondom die status van die aanvangsklinker van die prefiks en die pre-prefiks in Ndebele en ander Ngunitale. Dit kyk verder na die uitdagings en beperkings van die lemmatisering van die substantief deur óf die aanvangsklinker van die prefiks óf die aanvangsletter van die substantiefstam te gebruik. Daar word gevind dat daar ' $n$ aantal inkonsekwensies in die lemmatisering van leensubstantiewe met aanvangsklinkers en die toewysing van leensubstantiewe aan substantiefklasprefikse in die twee woordeboeke is. Hierdie inkonsekwensies het 'n negatiewe uitwerking op die standaardisering en behandeling van leensubstantiewe.

Sleutelwoorde: LEMMATISERING, MIKROSTRUKTUUR, MAKROSTRUKTUUR, GEBRUIKERSVOORKEUR, GEBRUIKERSPERSPEKTIEF, GEBRUIKERSVRIENDELIK, TOEGANKLIKHEID, OORTOLLIGHEID, SUBSTANTIEFSTAM, SUBSTANTIEFKLASPREFIKS, VOORVOEG, EGTE PREFIKS, LEENSUBSTANTIEF 


\section{Introduction}

A brief discussion of the morphological structure of the Ndebele noun, considering the grammatical status of its constituent morphemes, will serve as an introduction to this article. The noun class prefix distinguishes the class to which the noun belongs. It also denotes whether the noun is singular, plural or neuter. Furthermore it is the basis for the derivation of all substantival prefixes and concordial agreements dependent on it.

In Ndebele, as in all other Bantu languages, nouns are divided into different classes. The arrangement of Ndebele noun classes follows the accepted numbering applicable to all Bantu languages. There are 18 classes for Ndebele, with no nouns in classes 12 and 13. Classes 16, 17 and 18 reflect locative nominalisation. Some Ndebele noun class prefixes have allomorphs, which are phonologically conditioned according to the stem types they take. For example, class 7 /isi-/ has its allomorph /is-/, /isi-/ taking consonant-commencing stems such as isilwane (lion), isizwe (nation), isisu (stomach), and /is-/ taking vowel-commencing stems such as isono (sin), isothamlilo (human being) and isoni (sinner).

This system of noun classes must be mastered, as it is important for the correct speaking of the language. The noun class prefix is central, being the base of other substantival prefixes and concordial agreements of other word categories. Like other Nguni languages, Ndebele exhibits a peculiar feature in its noun class prefixes, the presence of the initial vowel or pre-prefix, or the augment, as Khumalo (2003: 80) calls it. Some noun class prefixes are just vowels as in classes 1a, 2a and 5. The initial vowel distinguishes Nguni languages from other Bantu languages. Apart from the initial vowel, a simple Ndebele noun is made up of the prefix proper and the stem as shown in $u$ (initial vowel) $-m u$ - (prefix proper) $-t h i($ stem) $=u-m u$-thi (medicine). The initial vowel is the

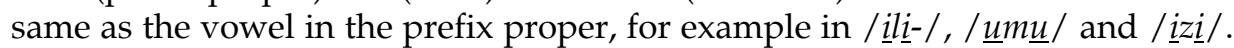
When a noun is used in its evocative sense the initial vowel is discarded, for example ndoda! (man!), mfana! (boy!) and mntwana! (child!). The initial vowel plays a complementary role to the prefix proper, in other words it augments it.

The grammatical status of the initial vowel is highly contentious, as there is no consensus on whether it is a syntactic, semantic or morphological feature. This initial vowel is, however, one of the unique distinguishing features of Ndebele. The controversies surrounding its grammatical status have led to inconsistencies among lexicographers and linguists in the lemmatisation of the noun in Ndebele and other Nguni languages, which share this same feature (Maphosa 1997: 1).

If the central role of the prefix in the derivation of substantival prefixes and concordial agreements is considered, it is undeniable that the subject and object concords, substantival prefixes and qualificative concords ought to be used as central criteria in deciding the class affiliation of borrowed nouns. These concords help clarify and distinguish the class affiliation of each given noun. 
The noun stem carries the central meaning of the word and does not change when the noun changes from singular to plural; it remains constant. It does not have any specific meaning until a prefix is attached to it (Hadebe 2006: 87). It is a bound morpheme, as it needs the prefix in order to give it a specific meaning. Ndebele noun stems come in different phonological forms; some are consonant-commencing, for example in-ja (dog), isi-nkwa (bread), in-doda (man), while others are vowel-commencing, for example is-ono (sin), is-ona (type of weed) and is-othamlilo (human being). Phonologically the noun stem in Ndebele ends in a vowel. Ndebele noun stems can be derived from other word categories, for example from verbs, relative stems, and adjectival stems among others. Some noun stems are primitive stems whose derivation cannot be traced, for example $-n t u$ for umuntu (person), -fazi for umfazi (woman) and -hlahla for isihlahla (tree).

In pioneering dictionaries, the lemmatisation of the noun in Ndebele and other related Nguni languages has been on the basis of the initial letter of the noun stem. The inconsistencies in the lemmatisation of the nouns in Ndebele and other Nguni languages are a clear testimony of the lack of consensus on the grammatical status of the initial vowel of the noun class prefix.

Apart from the omission of the initial vowel in vocatives, Von Staden (1973: 170) notes that the initial vowel is obligatorily omitted after possessive concords when they belong to class 1a, in a few instances after the locative possessive concord $k w a-$, in relative constructions, when they appear as second components of compound nouns, when used conjunctively, after negative associative copulatives, in interrogatives (such as in Ubona muntu bani? 'What sort of a person are you seeing?'), and when employed as relative stems.

Vowel elision and more commonly vowel coalescence result in the disappearance of the initial vowel. These processes are a means towards retaining the acceptable Ndebele syllable structure of $\mathrm{CV}$ or CCV which avoids cases where vowels follow each other in writing. Any one of these processes takes place if CVV, VVC or CCVV syllable structure occurs.

The realisation that the initial vowel is an individualising morpheme, because it distinguishes the meaning of nouns, proves beyond doubt that it is a semantic feature for it denotes class, person, gender and number. The fact that the initial vowel does not appear in the selected phonological conditions above is a clear testimony that it is part of the noun in Ndebele. The semantic value of the initial vowel makes it a necessary and indispensable morpheme that must be considered in lemmatising nouns, especially considering the primary and central role of meaning in lexicography. The semantic value of the initial vowel makes it a central feature that cannot be ignored in a field dealing primarily with meaning; hence, because of this semantic value, the Ndebele noun should be lemmatised using the initial vowel of the prefix.

\section{Lemmatisation of the noun in Nguni languages}

A cursory look at selected dictionaries in the Nguni family reveal that the noun 
has been lemmatised using the initial letter of the stem. Kropf (1899) lemmatises nouns according to the initial letter of the stem, on the grounds that the use of the initial vowel would crowd the majority of the headwords under the letters $i$ and $u$ since most of the nouns in these varieties have $/ i /$ and /or $/ u /$ as their initial vowel.

Doke and Vilakazi (1948) also follow the set principle in Nguni of lemmatising the noun using the initial letter of the stem, citing similar concerns and fears as Kropf. Of interest in their justification for this usage is their acknowledgement of the difficulties in identifying the initial letter of the stem. These two pioneering works clearly reveal the challenges of demarcating the noun stem as there are some remarkable inconsistencies in their identification of the initial letter of the stem of similar nouns, for example, Kropf's stem for impuphu (mealie-meal) is -puphu, and for Doke and Vilakazi the stem is -mpuphu. Doke and Vilakazi include the prefix proper $/ \mathrm{m} /$. This reveals the challenges that accompany lemmatising according to the initial letter of the stem, especially with regard to nasal-commencing stems.

Doke (1958) continues lemmatising the noun using the stem. Like the pioneers of Nguni lexicography, Nyembezi (1992) also lemmatises the noun according to the initial letter of the stem. Sometimes Nyembezi's initial letter of the stem begins with the prefix proper, revealing, as in the works of the other pioneers of Nguni lexicography, the controversies of what a stem is. Dent and Nyembezi (1969) follow Doke's way of lemmatising according to the initial letter of the stem, though with inconsistencies, since sometimes the stem incorporates the prefix proper, for example, -ntombi for intombi (maiden) and -mpi for impi (war). Nkabinde (1982 and 1985) also adopts Doke's way of lemmatising according to the initial letter of the stem. To mark the difference between the stem and the prefix, Nkabinde writes the stem in capital letters and the prefix in small letters.

It is clear that Nguni dictionaries reveal some significant inconsistencies in what a noun stem is. In some cases, the noun stem includes the prefix proper. In other cases, the noun stem is uncertain, especially when it is nasal-commencing. The inconsistencies reveal the challenges of demarcating the noun stem in Nguni and using it for lemmatising purposes.

\section{Lemmatisation of the noun in Ndebele}

The bilingual Ndebele dictionary of Pelling (1966) lemmatises the noun using the initial letter of the stem. The first monolingual general-purpose dictionary in Ndebele, Isichazamazwi SesiNdebele (henceforth ISN) lemmatises the noun using the initial vowel of the prefix. On the other hand, the first specialised Ndebele dictionary of musical terms, Isichazamazwi SezoMculo (henceforth ISM), reveals some inconsistencies in its lemmatisation of the noun. Vowel-commencing borrowed nouns are lemmatised using the initial letter of the stem while indigenous nouns are lemmatised using the initial vowel of the prefix. In the style manual the ISM editors note: 
Amagamanhloko angamabizo okwebolekwa aqala ngabonkamisa ethulwe ngalabonkamisa njengokuthi alitho, enkho ... Lapho atholakala khona phakathi kwengcazelo alotshwe ngamayitaliki elandela onsingankamisa / w/ loba / y/ kusiya ngabonkamisa beziqalo.

(Borrowed noun headwords which are vowel-commencing are lemmatised using those vowels as in alitho; enkho ... Where they are found in the definition they are written in italics following the semi-vowels /w/ or /y/ depending on the initial vowel of the prefix.)

The method of lemmatising vowel-commencing borrowed nouns is part of the major concern of this article, alongside the use of semi-vowels to break vowel sequencing in the ISN and ISM. The semi-vowel used for each borrowed noun also indicates the class to which that noun has been allocated, for example both iwolintshi (orange) and iyinki (ink) are allotted to class 5 in ISN. ISM's departure from ISN in the lemmatisation of vowel-commencing borrowed nouns impacts negatively on the standardisation of these terms, leaving users with an uncertain choice on how these should be written. ISN and ISM's use of the semivowels $/ w /$ and $/ y /$ to break vowel sequencing might not reflect all users' preference and speakers' usage of these terms, therefore violating acceptability (cf. Gilreath 1993: 91). Hadebe (2006: 183-184) notes that words such as iwoyili (oil) and iwoveni (oven) are pronounced by some people with the semi-vowel, while the majority does not do so. A form like *iyayini (iron) seems never to be used. The hyphen is sometimes used to break vowel sequencing not only in writing but also in pronouncing these terms, as in i-ayini, $i$-inki, $i$-olintshi, $i$-oyili and $i$-oveni. The use of the semi-vowels $/ w /$ and $/ y /$ affects the essential principles of term creation. For example, the ISM entries akhusitikhi/iyakhusitikhi (acoustic), adaphutha/iyadaphutha (adaptor) and ampulifaya/iyampulifaya (amplifier) sound ungrammatical, violating linguistic correctness (cf. Gilreath 1993: 89). However, there are cases such as iyuniformu (uniform), iyunivesithi (university) and iyembe (shirt) where the use of the semi-vowel is acceptable as long as these borrowed nouns conform to the principles of term creation and the speakers' pronunciation of them.

Significant in these examples from ISM are also the omission of the noun prefix. The treatment of vowel-commencing borrowed nouns as headwords without the noun prefix in ISM, for example $i$-akaphela as akhaphela (acapella), $i$ ophera as ophera (opera) and i-eriyeli as eriyeli (aerial), does not reflect their use by Ndebele speakers. They cease to be nouns if they are represented without the prefix. Here they are in their evocative state as interjections.

In their attempt to be normative, the ISN and ISM compilers should have striven to strike a balance between being descriptive and prescriptive in their treatment of vowel-commencing loan nouns. In accepting a loan word, it has to be adopted and adapted to suit the lexical, morphological, phonological and orthographic patterns of the recipient language. According to Béjoint (2000: 101), total prescriptiveness does not work if it is estranged from the realities of usage, as it is the case with ISN and ISM's use of borrowed headwords containing semi-vowels. The same is true of ISM's lemmatisation of vowel-com- 
mencing borrowed nouns using the initial vowel of the loan noun and denying them prefixes. This way of lemmatisation overlooks user-perspective because it is contrary to speakers' common usage. Users will therefore be challenged to locate these lemmas in the dictionary. This compromises the dictionary's accessibility which in turn translates into a less user-friendly dictionary. The inconsistencies in the lemmatisation of the noun in ISN and ISM impact negatively on the standardisation of these terms because of the variations in their treatment as headwords.

Apart from violating the above-mentioned terminological principles, the treatment of borrowed nouns presents challenges to users in deducing their word categories, especially considering the fact that ISM does not indicate word categories, granted that it is meant for specialised users. For the users to master the microstructure and continue using the dictionary without challenges, consistency in the treatment of common word categories is essential.

\section{Allocation of borrowed nouns to noun class prefixes in ISN}

In the Nguni languages and particularly in Ndebele, each noun belongs to a specific noun class prefix according to the following criteria (Canonici 1995: 14):

(a) shape of the noun prefix,

(b) correspondent singular/plural class,

(c) syntactic behaviour or the concords it requires, and

(d) semantic content.

Canonici argues that all these criteria must be used in combination to decide the class affiliation of a noun. Applying these criteria to borrowed nouns would therefore help to determine their class affiliation. A close look at most borrowed nouns in Nguni reveal that the majority of them fall under classes 5 and 9. However, there are some which are unambivalent in nature and fall either in class 5 or class 9, for example, among others, irandi (Rand) and isenti (cent). Testing the class affiliation of these unambivalent loan nouns, by using Canonici's criteria, confirm their unambivalent nature.

Table 1

\begin{tabular}{|l|l|l|l|l|l|l|l|c|}
\hline Entry & $\begin{array}{c}\text { Subj } \\
\text { Con }\end{array}$ & $\begin{array}{c}\text { Adj } \\
\text { Con }\end{array}$ & $\begin{array}{c}\text { Rel } \\
\text { Con }\end{array}$ & $\begin{array}{c}\text { Poss } \\
\text { Con }\end{array}$ & $\begin{array}{c}\text { Abs } \\
\text { Pro }\end{array}$ & $\begin{array}{c}\text { Dem } \\
\text { Pro }\end{array}$ & $\begin{array}{c}\text { Quant } \\
\text { Pro }\end{array}$ & Sel \\
\hline irandi (Rand) & $l i-/ i-$ & eli-/en- & eli-/e- & la-/ya- & lo-/yo- & leli/le & lo-/yo- & li-/i-/yi- \\
\hline isenti (cent) & $l i-/ i-$ & eli-/en- & eli-/e- & la-/ya- & lo-/yo- & leli/le & lo-/yo- & li-/i-/yi- \\
\hline $\begin{array}{l}\text { ithenisi (ten- } \\
\text { nis shoe) }\end{array}$ & $l i-/ i$ & eli-/en- & eli-/e & la-/ya- & lo-/yo- & leli/le & lo-/yo- & li-/i-/yi- \\
\hline
\end{tabular}

Abbreviations: Subj Con: Subject Concord, Adj Con: Adjectival Concord, Rel Con: Relative Concord, Poss Con: Possessive Concord, Abs Pro: Absolute Pronoun, Dem Pro: Demonstrative Pronoun, Quant Pro: Quantitative Pronoun, Sel: Selector 
A cursory look at ISN reveals that most of the borrowed nouns are slotted into class 5 , yet, as will be shown later in this section, they belong to class 9 allomorph or a proposed class 9a, for example: iwigi (wig), ithara (tar), itsheki (cheque), itafula (table), isepa (soap), irula (ruler), inalithi (needle), ipenda (paint), ifoni (telephone), ibhasi (bus), ibhenki (bank), ivayisi (vice), idivosi (divorce), isemantiki (semantics), iwaranti (warrant), isophurano (soprano), ikhiye (key), iyunifomu (uniform), isawa (sour milk), irekhodi (record), inayiloni (nylon), iKhisimusi (Christmas), ifulegi (flag), ikhofi (coffee), ifeni (fan), ibhata (butter), irisithi (receipt), igirisi (grease), ipheni (pen), ithoyi (toy), iselifoni (cell phone), irubhu (rubber rope), iyunivesithi (university), iyembe (shirt), ikhoma (comma), igirineda (grenade), ifenitsha (furniture), irediyo (radio), idisikoti (discord) and ibhera (bell).

According to Canonici (1995: 22), each class commands its own concordial system, dependent nominals and predicates, and these ought to be used alongside the other mentioned criteria to decide the class affiliation of borrowed nouns. There are, however, some Ndebele noun classes that share their concordial agreement. In these cases, testing for class affiliation must consider other tests such as shape of the prefix and correspondent singular/plural class further to ascertain the class affiliation of the nouns in question. Examples are classes 1, 1a and 3, 2 and 2a, 4 and 9, class 9 allomorph or a proposed class 9a, as well as classes 8 and 10. Classes 1 and 1a share concords because 1a is an allomorph of class 1 . The same is true for 2 and $2 a, 9,9 a$ and the proposed class 9 allomorph. For classes 1, 1a and 3, 4 and 9, class 9 allomorph or a proposed class $9 \mathrm{a}$, shape of the prefix and correspondent singular/plural class ought to be considered in these cases further to ascertain the class affiliation of the nouns in question. Class 5 is a singular class which is morphologically represented as /ili-/, this class has its allomorph / $i$-/ which is phonologically conditioned, mainly taking multisyllabic stems. The subject concord for this class is $/ l i /$. It realises its plurals in class 6 .

Class 9 is a singular class with most of its plurals in classes 10 and 6 . Examples of class 9 nouns that realise their plurals in class 6 are, among others, inkomokazi (cow), inkomitsho (cup), intombazana (young girl) and indoda (man). It is morphologically realised as $/ i \mathrm{~N}-/$, with the capital $N$ standing for either the nasal $/ n /$ or $/ m /$. Following the entering of borrowed nouns in Ndebele, there seems to be a growing new class of borrowed nouns which simply prefix / i/ without the nasal to the loan stem (Canonici 1995: 14). The noun class system of Ndebele already has this prefix in class 5 as an allomorph and this has tempted linguists and lexicographers to think that nouns that take/i-/ belong to class 5 , yet Canonici's test for class affiliation reveals that these borrowed nouns belong to class 9 allomorph or a proposed class 9 a.

For purposes of diminishing the number of classes, the proposed class $9 \mathrm{a}$ can be used as an allomorph for class 9 which will then have its allomorph / i-/ similar to other classes which have allomorphs, for example class 1 which has its allomorph /um-/. Canonici's proposal can even be adopted, as the Ndebele noun class system already reflects the class na as in class $1 \mathrm{a}$. What is essential is 
to realise that some borrowed nouns which take $/ i-/$ as their prefix are not class 5 nouns. Instead, they share the same concordial system, dependent nominals and predicates with class 9 .

The above realisation can be substantiated using the following examples:

$$
\begin{aligned}
& \text { iringi (ring) } \\
& \text { I-ringi i-lerusi } \quad * \text { I-ringi li } \underline{\text {-lerusi }} \text { (The ring is rusted). } \\
& \text { I-ringi ya-mi } \quad * \text { I-ringi la-mi (My ring). } \\
& \text { ijemu (jam) }
\end{aligned}
$$

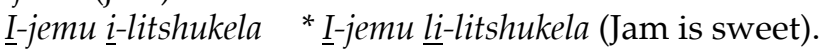

$$
\begin{aligned}
& \text { I-jemu ya-mi *I-jemu la-mi (My jam). }
\end{aligned}
$$

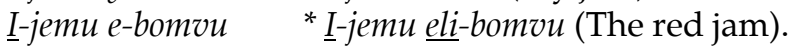

$$
\begin{aligned}
& \text { isenta (centre) } \\
& \underline{I} \text {-senta } \underline{i} \text {-banzi } \quad{ }^{*} \underline{I} \text {-senta } \underline{\text { li}} \text {-banzi (The centre is wide). } \\
& \text { I-senta } \underline{e} \text {-banzi } \quad{ }^{*} \underline{I} \text {-senta eli-banzi (The wide centre). }
\end{aligned}
$$

These nouns have their plurals in class 6 , just as the majority of those of class 5 . However, it should be noted that, as illustrated before, class 9 also has some of

\begin{tabular}{|c|c|c|c|c|c|c|c|c|}
\hline Entry in ISN & $\begin{array}{l}\text { Subj } \\
\text { Con }\end{array}$ & $\begin{array}{l}\text { Adj } \\
\text { Con }\end{array}$ & $\begin{array}{l}\text { Rel } \\
\text { Con }\end{array}$ & $\begin{array}{l}\text { Poss } \\
\text { Con }\end{array}$ & $\begin{array}{l}\text { Abs } \\
\text { Pro } \\
\end{array}$ & $\begin{array}{c}\text { Dem } \\
\text { Pro }\end{array}$ & $\begin{array}{c}\text { Quant } \\
\text { Pro }\end{array}$ & Sel \\
\hline iwigi (wig) & $i-$ & $e n-$ & $e-$ & $y a-$ & yo- & le & yo- & iphi/yiphi \\
\hline ithara (tar) & $i-$ & en- & $e-$ & $y a-$ & yo- & le & yo- & iphi/yiphi \\
\hline itsheki (cheque) & $i-$ & en- & $e-$ & $y a-$ & yo- & le & yo- & iphi/yiphi \\
\hline itafula (table) & $i-$ & en- & $e-$ & $y a-$ & yo- & le & yo- & iphi/yiphi \\
\hline isepa (soap) & $i-$ & en- & $e-$ & $y a-$ & yo- & le & yo- & iphi/yiphi \\
\hline irula (ruler) & $i-$ & en- & $e-$ & $y a-$ & yo- & le & yo- & iphi/yiphi \\
\hline inalithi (needle) & $i-$ & en- & $e-$ & $y a-$ & yo- & le & yo- & iphi/yiphi \\
\hline ipenda (paint) & $i-$ & en- & $e-$ & $y a-$ & yo- & le & yo- & iphi/yiphi \\
\hline ifoni (telephone) & $i-$ & en- & $e-$ & $y a-$ & yo- & le & yo- & iphi/yiphi \\
\hline ibhasi (bus) & $i-$ & en- & $e-$ & $y a-$ & yo- & le & yo- & iphi/yiphi \\
\hline ibhenki (bank) & $i-$ & en- & $e-$ & $y a-$ & yo- & le & yo- & iphi/yiphi \\
\hline ivayisi (vice) & $i-$ & en- & $e-$ & $y a-$ & yo- & le & yo- & iphi/yiphi \\
\hline idivosi (divorce) & $i-$ & en- & $e-$ & $y a-$ & yo- & le & yo- & iphi/yiphi \\
\hline isemantiki (semantics) & $i-$ & en- & e- & $y a-$ & yo- & le & yo- & iphi/yiphi \\
\hline iwaranti (warrant) & $i-$ & en- & $e-$ & $y a-$ & yo- & le & yo- & iphi/yiphi \\
\hline isophurano (soprano) & $i-$ & en- & $e-$ & $y a-$ & yo- & le & yo- & iphi/yiphi \\
\hline ikhiye (key) & $i-$ & en- & $e-$ & $y a-$ & yo- & le & yo- & iphi/yiphi \\
\hline iyunifomu (uniform) & $i-$ & en- & $e-$ & $y a-$ & yo- & le & yo- & iphi/yiphi \\
\hline isawa (sour milk) & $i-$ & en- & $e-$ & $y a-$ & yo- & le & yo- & iphi/yiphi \\
\hline irekhodi ( record) & $i-$ & en- & $e-$ & $y a-$ & yo- & le & yo- & iphi/yiphi \\
\hline
\end{tabular}
its plurals in class 6 . An application of Canonici's criteria reveals that the majority of the borrowed nouns in ISN are wrongly placed in class 5 . Instead, most of them belong to the class 9 allomorph or the proposed class $9 a$, as reflected by their syntactic behaviour or the concords they require (see Table 2).

\section{Table 2}




\begin{tabular}{|c|c|c|c|c|c|c|c|c|}
\hline Entry in ISN & $\begin{array}{l}\text { Subj } \\
\text { Con }\end{array}$ & $\begin{array}{l}\text { Adj } \\
\text { Con }\end{array}$ & $\begin{array}{l}\text { Rel } \\
\text { Con }\end{array}$ & $\begin{array}{l}\text { Poss } \\
\text { Con }\end{array}$ & $\begin{array}{l}\text { Abs } \\
\text { Pro }\end{array}$ & $\begin{array}{c}\text { Dem } \\
\text { Pro } \\
\end{array}$ & $\begin{array}{c}\text { Quant } \\
\text { Pro }\end{array}$ & Sel \\
\hline inayiloni (nylon) & i- & en- & $e-$ & $y a-$ & yo- & le & yo- & iphi/yiphi \\
\hline iKhisimusi (Christmas) & i- & en- & $e-$ & $y a-$ & yo- & le & yo- & iphi/yiphi \\
\hline ifulegi (flag) & $i-$ & en- & $e-$ & $y a-$ & yo- & le & yo- & iphi/yiphi \\
\hline ikhofi (coffee) & $i-$ & en- & $e-$ & $y a-$ & yo- & le & yo- & iphi/yiphi \\
\hline ifeni (fan) & $i-$ & en- & $e-$ & $y a-$ & yo- & le & yo- & iphi/yiphi \\
\hline ibhata (butter & $i-$ & en- & $e-$ & $y a-$ & yo- & le & yo- & iphi/yiphi \\
\hline irisithi (receipt) & $i-$ & en- & $e-$ & $y a-$ & yo- & le & yo- & iphi/yiphi \\
\hline igirisi (grease) & $i-$ & en- & $e-$ & $y a-$ & yo- & le & yo- & iphi/yiphi \\
\hline ipheni (pen) & $i-$ & en- & $e-$ & $y a-$ & yo- & le & yo- & iphi/yiphi \\
\hline ithoyi (toy) & $i-$ & en- & $e-$ & $y a-$ & yo- & le & yo- & $i-/ y i-$ \\
\hline iselifoni (cell phone) & $i-$ & en- & $e-$ & $y a-$ & yo- & le & yo- & $i-/ y i-$ \\
\hline irubhu (rubber rope) & $i-$ & en- & $e-$ & $y a-$ & yo- & le & yo- & iphi/yiphi \\
\hline iyunivesithi (university) & $i-$ & en- & $e-$ & $y a-$ & yo- & le & yo- & iphi/yiphi \\
\hline iyembe (shirt) & $i-$ & en- & $e-$ & $y a-$ & yo- & le & yo- & iphi/yiphi \\
\hline ikhoma (comma) & $i-$ & en- & $e-$ & $y a-$ & yo- & le & yo- & iphi/yiphi \\
\hline igirineda (grenade) & $i-$ & en- & $e-$ & $y a-$ & yo- & le & yo- & iphi/yiphi \\
\hline ifenitsha (furniture) & $i-$ & en- & $e-$ & $y a-$ & yo- & le & yo- & iphi/yiphi \\
\hline irediyo (radio) & $i-$ & en- & $e-$ & $y a-$ & yo- & le & yo- & iphi/yiphi \\
\hline idisikoti (discord) & $i-$ & en- & $e-$ & $y a-$ & yo- & le & yo- & iphi/yiphi \\
\hline ibhera (bell) & $i-$ & en- & $e^{-}$ & $y a-$ & yo- & le & yo- & iphi/yiphi \\
\hline
\end{tabular}

Abbreviations: Subj Con: Subject Concord, Adj Con: Adjectival Concord, Rel Con: Relative Concord, Poss Con: Possessive Concord, Abs Pro: Absolute Pronoun, Dem Pro: Demonstrative Pronoun, Quant Pro: Quantitative Pronoun, Sel: Selector

If the test for class affiliation in Table 1 is used, it becomes clear that these ISN entries belong to class 9 allomorph or Canonici's proposed class 9a. The following concordial agreements are derived:

\section{(1) Adjectival Concords}

Noun Class Qualificative Formative + Noun Class Prefix $=$ Adjectival Concord
9/9a
$a$
$i$ -
en-

(2) Relative Concords

Noun Class Qualificative Formative + Noun Class Prefix = Relative Concord
$9 / 9 \mathrm{a}$
$a$
$i-$
$e-$

In the derivation of the adjectival and relative concords in (1) and (2), vowel coalescence takes place when the qualificative formative, $a$-, is prefixed to the full prefix. For the relative concord, all nasal consonants and vowels that follow them are elided in its derivation.

(3) Possessive Concords

Noun Class Subject Concord + Qualificative Formative $=$ Possessive Concord

$$
\text { 9/9a i- } \quad a \quad y a-
$$

In deriving the possessive concord in (3), the subject concord is consonantised 
and becomes a semi-vowel $/ y /$. This happens to retain the acceptable Ndebele syllable structure.

(4) Selector Concords

$$
\begin{array}{cccc}
\text { Noun Class } & \text { Subject Concord }+ \text { Selector Roots } & =\text { Selector Concord } \\
9 / 9 a & i- & -p h i & i p h i / \text { yiphi }
\end{array}
$$

In (4), the selector concord is derived from the copulative prefix / yi/.

(5) Absolute Pronoun

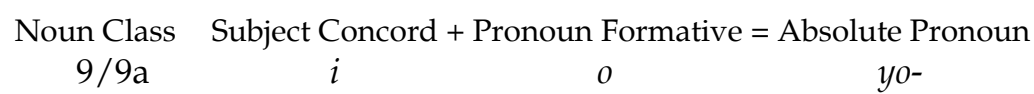

In deriving the absolute pronoun in (5). the subject concord is consonantised and becomes a semi-vowel $/ y /$. As in (3), consonantisation takes place to retain the acceptable Ndebele syllable structure.

(6) Demonstrative Pronoun

$\begin{array}{cccc}\text { Noun Class } & \text { Demonstrative Formative }+ \text { Noun Class Form } & = & \text { Demonstrative Pronoun } \\ 9 / 9 a & l a & i- & l e\end{array}$

In (6), vowel coalescence takes place between the final vowel of the demonstrative formative and the initial vowel of the prefix. In cases where the prefix is followed by nasal consonants, the nasal and the vowel that follow it are elided.

(7) Quantitative Pronoun

$$
\begin{array}{cccc}
\text { Noun Class } & \text { Subject Concord }+ \text { Pronoun Formative }=\text { Quantitative Pronoun } \\
9 / 9 \mathrm{a} & i- & 0 & \text { yo- }
\end{array}
$$

In (7), consonantisation of the subject concord takes place to retain the acceptable Ndebele syllable structure.

The classes dealt with here regarding borrowed nouns are traditionally problematic classes; hence, this problem is not unique to Ndebele. Zawawi (1979: 127), writing about Swahili, suggests that such nouns may first be incorporated into class 9, and may later be recategorised as class 5 , the latter having the advantage of distinguishing singular from plural. Eastman (1991: $61 \mathrm{ff}$.) argues the reverse: that borrowed nouns should start out in class 5 and should later be recategorised as belonging to class 9 .

The confusion of classes for borrowed nouns has a negative influence on the language since the mastering of the noun class system is central to speaking Ndebele correctly. Grammatical information has to be as accurate as the definitions in the dictionary. For a language like Ndebele that lacks comprehensive documentation and grammar books, the inclusion of grammatical information cannot be underestimated. Because of this, the centrality of the noun class prefix makes it essential to give the correct class to each noun, since it is important 
for the derivation of the subject and object concords, other dependent substantival prefixes and qualificative concords in languages like Ndebele.

\section{The merits and demerits of lemmatising nouns using the stem}

Lemmatisation of nouns in the ISN and ISM cannot be discussed without focusing on user-perspective, an issue that has emerged as one of the important lexicographical subjects in the selection and treatment of lexical items, in this case the adoption and adaptation of loan words. As Prinsloo (2001: 18) notes, a dictionary should not reflect the attitude of the lexicographer but should rather be aimed at the specific needs of well-defined target users. It must also be compiled according to the needs and usage skills of the target users. It is against this background that the merits and demerits of lemmatising the noun using the initial letter of the stem or the initial vowel of the prefix are discussed.

There seems to be more demerits than merits in using the initial letter of the stem for lemmatising the noun in Ndebele and other Nguni languages. According to Maphosa (1997: 27), one advantage of lemmatising according to the initial letter of the stem is that related nouns are entered in the same place, that is, nouns sharing semantically related stems are grouped together. However, users usually do not consult a dictionary in search of semantically related words. They consult a dictionary when they come across separate words whose meaning and use they want to clarify. Furthermore, if thesauruses can equally and effectively list semantically related terms together, lemmatisation for this reason can be left to them. The naturalness of the language is compromised when lemmatisation takes place according to the initial letter of the stem since the initial vowel of the prefix is the one defining and distinguishing feature of Nguni languages.

The systematic ordering of nouns using the initial letter of the stem to achieve a semantic ordering of entries gives the impression that language consists of strings of semantically related words, which is not the case. In fact, some of these identical stems are semantically unrelated. For example:

-zulu i-zulu (rain) vs -zulu $u$-m-zulu/a-ba-zulu (Zulu person/Zulu people).

-fo $u$ - $m$-fo $a b a-f o$ (enemy/enemies) vs -fo $i$-si-fo/i-zi-fo (infection/infections).

-tshe $i$-li-tshe/a-ma-tshe (stone/stones) vs -tshe $i$-n-tshe/i-zi-ntshe (ostrich/ ostriches).

-ngane $i$-ngane (child) vs -ngane $>u$-m-ngane (friend).

-thebe $i$-si-thebe (eating vessel) vs -thebe $>i$-thebe (hip bone).

Maphosa (1997: 23) also notes that the use of the initial letter of the stem in lemmatising noun headwords in Nguni dictionaries enhances the quality of the layout of these dictionaries. In as much as the use of the initial letter of the stem allows for the even distribution of headwords in the dictionary across all the 
letters of the alphabet, it is however a natural characteristic of Nguni languages that the majority of their entries belong to certain letters. The major limitation of the system of lemmatising nouns using the initial letter of the stem is that it compromises the naturalness of the language by denying the noun its major distinguishing feature. The stem is also not easily identifiable as reflected within and among dictionaries of Nguni languages that often contain inconsistencies in and variations of the stems for similar nouns. This in turn renders the method less user-friendly for users might look for the entry under the wrong letter, wasting their time. It also makes the dictionary less accessible, because, in most cases when users consult dictionaries, they would normally be engaged in some linguistic activity, for example translation, which they would not want to interrupt for too long. In addition, this method is not in line with common usage of the noun in Nguni. In everyday speech or interaction, speakers of Nguni languages do not use the noun stem but the complete noun with its prefix and stem. It is only in evocative and interrogative usage that they drop the initial vowel of the prefix.

Another major limitation of using the initial letter of the stem in lemmatising the noun is that it requires prior linguistic knowledge and training for users to access the entry for which they would be searching. This same linguistic knowledge and training would be required from lexicographers to lemmatise nouns according to their stems.

According to Doke (1993: 196), stems are not words, because they are bound morphemes, not having meaning on their own. As the noun class prefixes, they cannot stand on their own, and hence they cannot be seen and used as entries. The noun stem needs a prefix to enable it to distinguish class, number, gender and person, so as to convey its full meaning. It is only when stems are attached to the prefix that they become words. In common usage, users will never come across a text that refers only to the noun stem. A noun consists of two components; therefore the initial vowel of the prefix ought to be considered in lemmatising nouns.

The above limitations of lemmatising using the initial letter of the stem all point to the dictionary's compromise of user-friendliness because this method impacts negatively on the relative ease with which information can be accessed in the dictionary. It leads to an ambiguous retrieval of information on both the macro- and microstructural levels of the dictionary.

\section{The merits and demerits of lemmatising using the initial vowel of the prefix}

Lemmatising noun headwords using the initial vowel of the prefix is more user-friendly, making the information in the dictionary more accessible to users. It provides a mode of access that is convenient for and common to them. Consulting a dictionary does not require any prior linguistic knowledge and training for users, therefore making it easy and quick to access the information 
in the dictionary. This method is therefore in line with common usage of the noun in Ndebele, users' expectations and preferences.

Use of the initial vowel of the prefix in lemmatising noun headwords represents the noun in its original form in the language and in the way in which users utter and write the Ndebele noun. It leads to an unambiguous retrieval of information presented in both the macro- and microstructure of the dictionary. The approach is in line with the morphological structure of the Ndebele noun. Above all, it reflects the semantic value of the initial vowel, indicating that it is not merely a syntactic feature.

Maphosa (1997: 35) notes that the demerit of lemmatising noun headwords using the initial vowel of the prefix is that it results in an uneven distribution of headwords across the letters of the alphabet. This is not much of a demerit as Maphosa also acknowledges, it is just a reflection of the nature of a specific language.

The argument that the lemmatisation of headwords using the initial vowel of the prefix takes up much space can be addressed by entering only the singular and neutral forms as headwords. Plural forms with existing singular forms would then be avoided, since the noun class system will be clearly and adequately explained, allowing users to deduce the plural forms by themselves, guided by the table of noun classes in the front matter of the dictionary. Inclusion of such information will complement efforts of making an exposition of Ndebele grammar available.

Because space is critical in a dictionary, no dictionary is spared the necessity of saving space (Landau 2001: 375). Entering nouns in their singular form is one method ISN adopts as a space-saving device. Hadebe (2002: ixxxiv) notes:

Isichazamazwi lesi siqukethe amabizo aphawula ubunye. Lokhu kwenzelwe ukulondoloza indawo egwalweni kanti futhi uma igama selivele lachazwa akudingeki ukubona lichazwe njalo selikhomba ubunengi ngoba ingcazelo iyabe ilokhu ifana.

(This dictionary contains nouns that are in their singular form. This has been done to save space in the dictionary and when a noun has been defined there is no need to see it defined again in its plural form since the meaning will still be the same.)

However, in ISM some nouns are entered in both their plural and singular forms, for example izihlangu (shields) and amabhetshu (loin skins). It should not be denied that for some, common usage reflects their use in the plural or collective form, hence requiring them to be entered as plurals, for example amahlwayi (leg rattles), izikeyi (wooden clappers) and amangqongqo (beads). A plural such as amanothi (notes) is for example defined to capture a slightly different sense from the singular inothi (note). It is, however, necessary to avoid entering both the plural and singular forms where a singular form can be used.

For the sake of the user-friendliness of the dictionary and the accessibility of its contents, it is worthwhile to lemmatise using the initial vowel of the prefix. This approach preserves and reflects the language in its natural state, representing the noun headword in a manner that is familiar to the user in speech 
and writing. It does not require prior linguistic knowledge and training from the user to accurately identify the stem of the noun and locate it in the dictionary. In other words, as Hadebe (2002: xxii) notes, the method of lemmatising the stem does not reflect common usage of the noun in a way familiar to users:

Lokhu kwethula amabizo kutsho ukuthi nxa obalayo engenelisi ukwahlukanisa igama ngezakhi zalo angeke alithola lula ibala alidingayo.

(This method of lemmatising nouns means that if the user is not able to segment the noun by its morphemes he/she cannot find the word he/she is searching for.)

The controversies on where the stem begins complicate decisions for the compilers, leading to inconsistencies within a dictionary and among dictionaries for similar noun headwords and those sharing the same stem. From the perspective of the users, the consultation process is even more complicated because they would not know for certain under which letter to find the entry.

Furthermore, the centrality of the noun prefix in the derivation of concordial agreements and other dependent substantival prefixes makes it necessary to lemmatise using the initial vowel of the prefix, which, with the prefix proper, is the base prefix. In addition to this, it is the noun class prefix in Ndebele, which denotes number in terms of singular, plural or neuter. In the Nguni languages, the noun prefix is therefore more than a syntactic feature. Except for natural gender, it expresses the categories of number and person, making it a semantic feature than cannot be ignored in a field where meaning is the focal point. The fact that the noun class prefix and the noun stem are bound morphemes means they cannot stand separately as entries because in this form they do not constitute words. It is therefore linguistically proper to lemmatise using the initial vowel of the prefix for the entries to be called words and more precisely Ndebele nouns.

\section{Conclusion}

It has been argued that the treatment and lemmatisation of vowel-commencing borrowed nouns should occur in a way that satisfies the decoding needs of the target users. It must at the same time help the encoding needs of the users in providing sufficient help for them to produce correct vowel-commencing loan nouns in speech and writing. It has also been pointed out that lemmatising using the initial vowel of the prefix enhances information retrieval strategies, being in line with user-perspective and -preference because it presents the noun in a way familiar and common to the user. This way of lemmatising has the advantage of easy reference, rendering the dictionary more user-friendly and accessible. In addition to this, it is in line with the principles of term creation discussed in the article. On the other hand lemmatising using the initial letter of the stem is subject to many limitations and demerits which render the dictionary less user-friendly and accessible. With regard to the adoption and 
adaptation of vowel-commencing borrowed nouns, it has been noted that the use of semi-vowels to break vowel sequencing is not ideal in all instances. Although there are cases where it works, by and large this does not seem to be the best method for breaking vowel sequencing. Except that this method violates the principles of term creation, it compromises user-preference and -perspective. With regard to the lemmatisation and treatment of vowel-commencing loan nouns in ISN and ISM the compilers' use of semi-vowels to break vowel sequencing overlooks the linguistic and communicative needs of the target users in both the selection and treatment of these nouns at the micro- and macrostructural levels. Finally, with regard to the allocation of borrowed nouns to noun class prefixes, Canonici's set of criteria ought to be used in determining the class affiliation of each borrowed noun and an emerging class 9 allomorph or class $9 \mathrm{a}$ which is morphologically realised as $/ i-/$ has been recommended for the majority of the borrowed nouns allocated to class 5 in ISN.

\section{References}

\section{Primary Sources}

Dent, G.R. and C.L.S. Nyembezi. 1969. Scholar's Zulu Dictionary: English-Zulu, Zulu-English. Pietermaritzburg: Shuter and Shooter.

Doke, C.M. and B.W. Vilakazi. 1948. Zulu-English Dictionary. Johannesburg: Witwatersrand University Press.

Doke, C.M. et al. 1958. English-Zulu Dictionary. Johannesburg: Witwatersrand University Press.

Hadebe, S. et al. (Eds.). 2002. Isichazamazwi SesiNdebele. Harare: College Press.

Kropf, A. 1899. A Kaffir-English Dictionary. King William's Town: Lovedale Mission Press.

Nkabinde, A.C. 1982. Isichazamazwi 1. Pietermaritzburg: Shuter and Shooter.

Nkabinde, A.C. 1985. Isichazamazwi 2. Cape Town: Oxford University Press.

Nkomo, D. and N. Moyo (Eds.). 2006. Isichazamazwi SezoMculo. Gweru: Mambo Press.

Nyembezi, C.L.S. 1992. AZ: Isichazamazwi sanamuhla nangumuso. Pietermaritzburg: Reach Out Publishers.

Pelling, J.N. 1966. A Practical Ndebele Dictionary. Harare: Longman Publishers.

\section{Secondary Sources}

Béjoint, H. 2000. Modern Lexicography: An Introduction. Oxford: Oxford University Press.

Canonici, N.N. 1995. Elements of Zulu Morph-Syntax. Zulu Language and Literature. Durban: University of Natal.

Doke, C.M. 1993. Trekking in South Central Africa, 1913-1919. Edited by R.K. Herbert. Johannesburg: Witwatersrand University Press.

Eastman, C.M. 1991. Loanwords and Swahili Nominal Inflection. Blommaert, J. (Ed.). 1991. Swahili Studies: Essays in Honour of Marcel van Spaandonck: 57-77. Ghent: Academia Press. 
Gilreath, C.T. 1993 Onometrics: The Formal Evaluation of Terms. Strechlow, R.A. and S.E. Wright (Eds.). Standardising Terminology for Better Communication. Oxford: Basil Blackwell.

Hadebe, S. 2006. The Standardisation of the Ndebele Language through Dictionary-Making. Unpublished D.Phil. Dissertation. Harare/Oslo: University of Zimbabwe/University of Oslo.

Khumalo, L. 2003. A General Introduction to Ndebele Grammar. Harare: University of Zimbabwe Publications.

Landau, S.I. 2001. Dictionaries: The Art and Craft of Lexicography. Second Edition. Cambridge: Cambridge University Press.

Maphosa, M. 1997. The Morphological Structure of the Ndebele Noun and Implications on the Ordering of Entries in Ndebele Dictionaries. Unpublished B.A. Hons. Thesis. Harare: University of Zimbabwe.

Prinsloo, D.J. 2001. The Compilation of Electronic Dictionaries for the African Languages. Lexikos 11: 139-159.

Von Staden, P.M.S. 1973. The Initial Vowel of the Noun in Zulu. African Studies 32 (3): 163-181.

Zawawi, S.M. 1979. Loanwords and their Effect on the Classification of Swahili Nominals. Leyden: E.J. Brill. 